\title{
CERTAIN ASPECTS OF TYROSINE METABOLISM IN THE YOUNG. I. THE DEVELOPMENT OF THE TYROSINE OXIDIZING SYSTEM IN HUMAN LIVER ${ }^{1}$
}

\author{
By NORMAN KRETCHMER, S. Z. LEVINE, HELEN MCNAMARA, AND \\ HENRY L. BARNETT \\ (From the Department of Pediatrics, The New York Hospital-Cornell Medical Center, \\ New York, N. Y.)
}

(Submitted for publication September 12, 1955; accepted October 31, 1955)

The major pathway for tyrosine catabolism in the animal is the non-oxidative transamination of tyrosine to p-hydroxyphenylpyruvate and its subsequent oxidation to homogentisate. The homogentisate is oxidized to fumarylacetoacetate (maleylacetoacetate), which is finally hydrolyzed to fumarate (malate) and acetoacetate. The enzyme system responsible for this catabolism, tentatively called the tyrosine oxidizing system, is soluble and a partial purification can be accomplished with high speed centrifugation of homogenates of liver (1) and kidney (2). When these preparations are used it has been observed (3) that one mole of tyrosine will be completely oxidized to one mole of acetoacetate and one mole of fumarate, with the utilization of two moles of oxygen. In order to obtain maximal tyrosine transaminase activity it is necessary to add $\alpha$-ketoglutarate and pyridoxal phosphate in vitro. The oxidation of the formed $\mathrm{p}$-hydroxyphenylpyruvate requires ascorbic acid $(1,4,5)$ as a cofactor or an equivalent oxidation-reduction substitute such as dichlorophenolindophenol $(6,7)$.

Clinically, it was shown $(8,9)$ that premature infants maintained on a diet high in protein without added ascorbic acid excreted p-hydroxyphenylpyruvic acid in their urine. Similarly, p-hydroxyphenylpyruvic acid was excreted in the urine of scorbutic adults $(10,11)$. The addition of ascorbic acid to the diet of both groups resulted in the disappearance of this substance from the urine. It was also observed that when large doses of pteroylglutamic acid were given to scorbutic guinea pigs (12), monkeys (13), and prema-

\footnotetext{
1 This investigation was supported in part by research grants from The National Institute of Arthritis and Metabolic Diseases of the National Institutes of Health, Public Health Service (A-389), from The New York Heart Association and from The Jaffe Fund for Premature Infants.
}

ture infants (14) there was a decrease in keto acid excretion. ACTH, after a latent period, also decreased the excretion of p-hydroxyphenylpyruvic acid by premature infants (15) and scorbutic guinea pigs (16). The mode of action of pteroylglutamic acid and ACTH is still obscure. In contradistinction to the above findings it was observed that in two of the three reported adult cases of tyrosinosis there was no effect of ascorbic acid on the urinary excretion of tyrosine or of p-hydroxyphenylpyruvic acid (3).

These investigations are concerned with the relationship of growth of the organism to the development and action of the tyrosine oxidizing system. The data obtained from premature infants, immature rats, and older subjects will be used in an effort to explain the previous results in terms of a developing enzyme system.

\section{METHODS}

\section{Subjects}

Samples of liver from premature infants, newborn infants and adults were obtained at autopsy. ${ }^{2}$ All donors were clinically free of hepatic disease and their livers showed no gross evidence of liver pathology. The mothers of all premature infants had uneventful pregnancies. Special precautions were taken to obtain the livers from the premature infants as soon after death as possible. These infants were removed to the morgue refrigerator; the autopsy was promptly performed and liver samples obtained.

Livers from all subjects were immediately placed in a chilled beaker which was kept on ice and transported to the laboratory for immediate preparation. The data on human subjects are summarized in Table I.

Samples of adult animal livers were obtained from the Long-Evans strain of rats following sacrifice by a blow to the head. The liver was quickly removed and rinsed with ice-cold 0.9 per cent $\mathrm{KCl}$ to remove adherent

2 The authors acknowledge the assistance of Dr. Arthur Carlson of the Department of Pathology, and the Pediatric House Staff in obtaining the specimens. 
TABLE I

Summary of clinical data

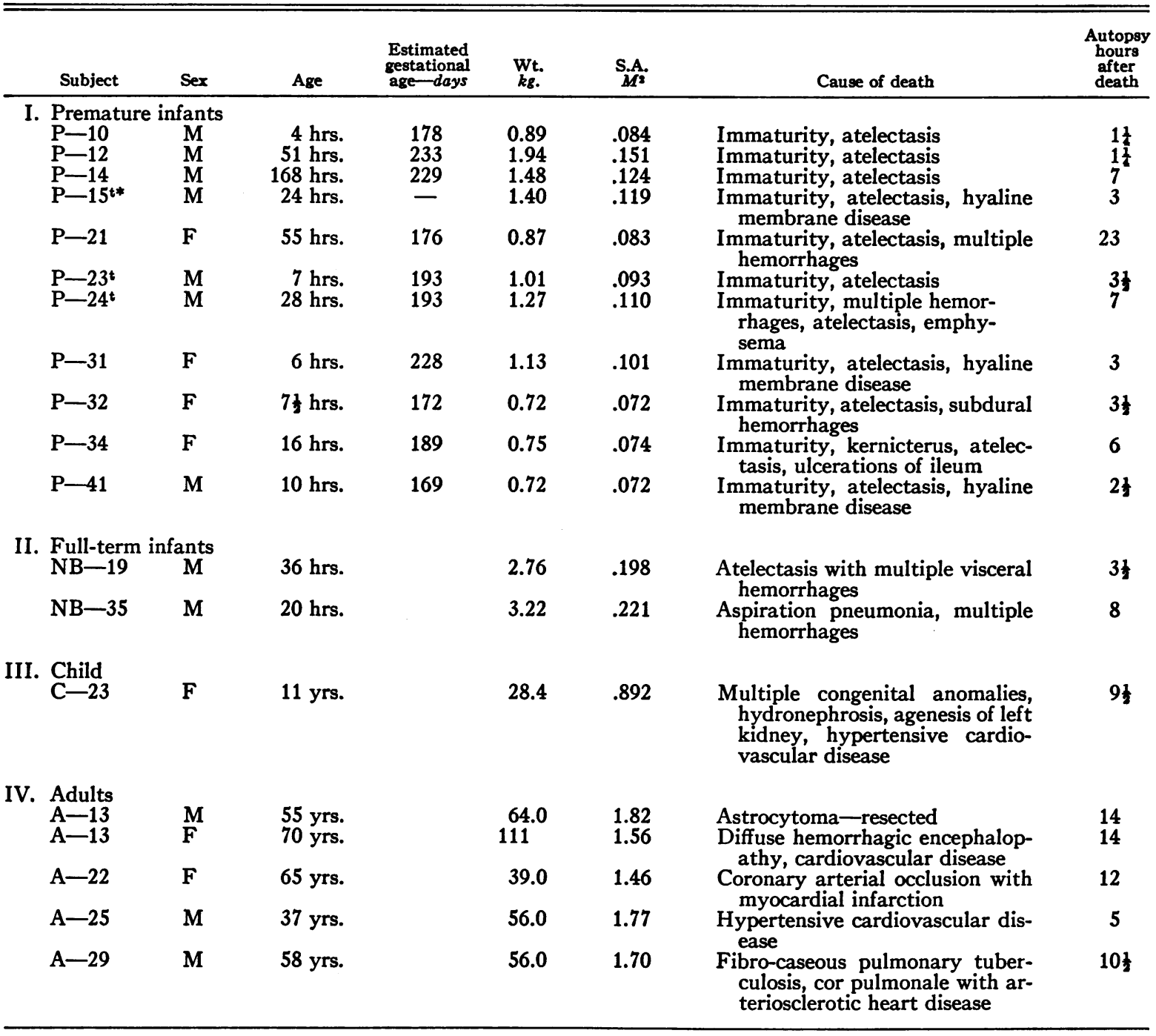

$* t=$ twin.

blood prior to grinding. Infant and newborn rats were sacrificed by decapitation or decerebration and exsanguinated. Fetal rats were removed from a pregnant animal and decapitated. The livers from all of the groups were removed immediately for tissue preparation except in the case of those rats which were permitted to remain for varying periods in the cold room (temperature 2 to $4^{\circ} \mathrm{C}$ ) or at room temperature (26 to $28^{\circ} \mathrm{C}$ ) to assay the effect of these factors on the hepatic tyrosine oxidizing system. Only litter mates were compared in these experiments. ${ }^{8}$

8 The effect of varying conditions following autopsy on the tyrosine oxidizing system was studied by killing infant rats by different techniques and exposing them after death to room temperature for varying time intervals

\section{Preparation of tissue}

Human and rat livers were immediately placed in a dish on ice in the cold room for prompt and complete preparation of samples. Generally, the human liver was pressed through a hand-tissue press with a sieve of $1 \mathrm{~mm}$. diameter holes to remove connective tissue mechanically. (17). No differences in oxidative activity resulted when the animals were sacrificed with and without complete exsanguination. Rats exposed to room temperature for three hours showed no change in oxidative activity, but exposure for six hours resulted in a decrease in activity. The decrease was proportional to a rising level of homogentisic acid which was undoubtedly due to the decrease in the $\mathrm{pH}$ of the liver and the subsequent inhibition of homogentisic acid oxidase (3). 
The resultant mash was ground for two minutes in a Waring Blendor with one to three volumes of ice-cold 0.9 per cent $\mathrm{KCl}$. No difference in oxidative activity was observed whether the homogenates were prepared in the Waring Blendor or the Teflon-glass homogenizer. The rat tissue was homogenized in the Teflon homogenizer because of the small amount of sample. In the case of the infant rats, it was necessary to pool two to four livers to provide a sufficient quantity of tissue. Following homogenization the volume was measured and aliquots were centrifuged in the Sorvall SS-1 centrifuge at $18,000 \times \mathrm{g}$ for 15 minutes. The resultant supernatant fluid or soluble fraction was collected and the volume measured. It was found that a force of $100,000 \times \mathrm{g}$ for 30 minutes in the Spinco centrifuge Model L did not decrease the oxidative activity, indicating that the enzyme was soluble (1). In some instances the soluble fraction was dialyzed against tap water in the cold overnight and the activity of the dialyzed material was measured. This modification of the procedure suggested by Knox and LeMay-Knox (1) was found to be simpler and less erratic than the use of acetone powders (18) or sucrose as a solvent (19).

\section{Measurement of oxidative activity}

Measurements were made with the total homogenate, the soluble fraction resulting from high-speed centrifugation and the dialyzed soluble fraction. Samples $(0.30$ to $1.00 \mathrm{ml}$.) were placed in previously prepared Warburg flasks with sidearms, the flask contents being essentially those described by Knox and LeMay-Knox (1). Besides the liver samples, the flasks contained $2.0 \mathrm{ml}$. of $0.2 \mathrm{M}$ phosphate buffer $\mathrm{pH} 7.4,8 \mu \mathrm{M}$ of tyrosine, and $0.2 \mathrm{ml}$. of an ascorbic acid solution $(.250$ to $5 \mathrm{mg}$.) adjusted to $\mathrm{pH} 7.4$. The sidearm contained $0.3 \mathrm{ml}$. of $\alpha$-ketoglutarate $(30 \mu \mathrm{M})$ adjusted to $\mathrm{pH} 7.4$ and $0.2 \mathrm{ml}$. of pyridoxal phosphate $(60 \mu \mathrm{g})$..4 The center well contained $0.2 \mathrm{ml}$. of 20 per cent $\mathrm{KOH}$ on a strip of filter paper in order to absorb carbon dioxide. Glass distilled water was added to the main central compartment to bring the total volume to $3.7 \mathrm{ml}$. A control flask lacking tyrosine but containing all of the other reactants was run with each tissue sample. The "endogenous" oxygen uptake was measured and deducted from the oxygen uptake of the flasks containing tyrosine. Measurements were made at $37.3^{\circ} \mathrm{C}$ and were started after an equilibration period of 10 minutes at which time the contents of the sidearms were tipped into the main portion and the stopcocks were closed. Readings were taken at 10-minute intervals for a total period of 60 minutes. When measurements were made in an atmosphere of nitrogen the flasks were "gassed" on the bath during the 10-minute equilibration period. Following closure of the stopcocks, readings were taken to preclude the extraneous uptake of oxygen.

4 The authors wish to thank Dr. Kenneth Tsuboi for his generous contribution of pyridoxal phosphate.

\section{Chemical determinations}

Nitrogen determinations were made on aliquots of the original liver tissue by the Ma-Zuazaga modification of the micro-Kjeldahl method (20). An additional aliquot of the total homogenate was treated according to a modification of the Schneider trichloroacetic acid fractionation method (21) and desoxyribonucleic acid was determined on the fraction remaining after the sample was first treated with an equal volume of ice-cold 10 per cent trichloroacetic acid and alcohol-ether. The final precipitate was heated with 5 per cent trichloroacetic acid for 15 minutes at $90^{\circ} \mathrm{C}$ and the desoxyribonucleic acid was determined in the supernatant fluid with the diphenylamine reaction (22).

Immediately following completion of measurements of oxidative activity, the contents of the Warburg flasks were removed and aliquots were placed in equal volumes of trichloroacetic acid (TCA) and metaphosphoric acid to make 5 per cent solutions. The protein precipitate was removed from both of these suspensions by centrifugation. From the supernatant fluid of the TCA precipitation, an aliquot was taken for the determination of Briggs reacting material (p-hydroxyphenylpyruvic acid, homogentisic acid, and also ascorbic acid) according to a modification of the method of Medes (23). In order to remove interference from ascorbic acid an aliquot from the trichloroacetic acid solution was extracted three times with peroxide-free ether. This ether extract containing p-hydroxyphenylpyruvic acid and homogentisic acid was evaporated to dryness and the Briggs' reaction was performed as outlined by Medes. Similar treatment of pure solutions of p-hydroxyphenylpyruvic acid gave recoveries of approximately 70 to 75 per cent. The original trichloroacetic acid filtrate prior to ether extraction was utilized directly for the determination of homogentisic acid by the iodometric method of Neuberger and Webster (24).

In order to determine micro-quantities of homogentisic acid, $.001 \mathrm{~N}$ thiosulfate and $.001 \mathrm{~N}$ iodine were used. To estimate maleylacetoacetic acid, another aliquot of the trichloroacetic acid extract was read in the Beckman DU spectrophotometer with a blank prepared from the TCA extract of the specific control flask. Acid solutions depress the ultraviolet absorption of maleylacetoacetic acid (3) but readings of samples showing oxidative activity at wave lengths of $300 \mathrm{~m} \mu$ to $345 \mathrm{~m} \mu$ showed a band which was not present in the tissue blanks or in samples incubated in an atmosphere of nitrogen. The absorption of the p-hydroxyphenylpyruvic acid was compensated for by the addition of an equivalent amount of p-hydroxyphenylpyruvic acid to the tissue blank against which the samples incubated in nitrogen were read. Under these conditions the presence of an absorption curve at $300 \mathrm{~m} \mu$ to $345 \mathrm{~m} \mu$ was taken as an estimate of the presence of maleylacetoacetic acid.

The metaphosphoric acid extract was used for measurement of p-hydroxyphenyl compounds (24): tyrosine and p-hydroxyphenylpyruvic acid. To avoid turbidity, these samples were read as soon as they became optically 
constant, approximately three minutes after the sodium nitrite was added. The remainder of the metaphosphoric acid extract was used for the formation and determination of 2-4 dinitrophenylhydrazones according to the methods of Cavallini and Frontali (25). The metaphosphoric acid filtrate was first extracted three times with peroxide-free ether in order to remove $p$-hydroxyphenylpyruvic acid and leave the $\alpha$-ketoglutaric acid in the residue. It was found that $\alpha$-ketoglutaric acid, being in much greater concentration than the aromatic keto acid, interfered with the chromatograms in the absence of ether extraction. The hydrazones which were formed on addition of 2-4 dinitrophenylhydrazine were chromatographed with n-butanol (25) as the moving solvent on Whatman No. 3 strips. A few drops of formic acid were placed in the drum to prevent tailing. The p-hydroxyphenylpyruvic acid migrated as two spots due to the syn-anti configuration and gave $R_{\ell}$ values of 0.83 and 0.96. Pure homogentisic acid and p-hydroxyphenylpyruvic acid for use as standards were obtained through the courtesy of Dr. W. Eugene Knox and the latter was also purchased from the Homberg Chemiewerk, Frankfurt am Main.

\section{RESULTS}

The data in Table I show that 10 of the 11 liver specimens from premature infants were obtained within 7 hours after death. The weight of the infants ranged from $.72 \mathrm{~kg}$. to $1.94 \mathrm{~kg}$. and their gestational age, from 169 to 233 days with a mean of 196 days. Specimens from full-term infants and adults were obtained within 14 hours after death.

The data in Table II present the oxidative activities obtained with the total homogenate, the soluble fraction derived from high speed centrifugation and the dialyzed soluble fraction. Since this enzyme system is soluble it will be noted that when enzyme activity is rated on the basis of nitrogen it consistently increased in the adult and full-term infant livers as the nonactive particulate matter was removed. In contrast, this increase was noted in the soluble fraction of only 2 of the 11 premature infant livers and in terms of the nitrogen standard was negligible. The liver from the premature infant obtained 23 hours after death (P-21) showed virtually the highest activity both on the basis of wet weight and nitrogen. The hepatic activity of the full-term infants and the adults was 3 to 20 times greater than that of

TABLE II

The activity of the tyrosine oxidizing system in fractions of human liver

\begin{tabular}{|c|c|c|c|c|}
\hline Subject & $\begin{array}{c}\text { Homogenate } \\
\mu l . O_{z} / 30^{\prime} / g m \text {. wet wt. }\end{array}$ & Homogenate & $\begin{array}{c}\text { Soluble } \\
\text { fraction } \\
\mu l . O_{2} / 30^{\prime} / m g . N\end{array}$ & $\begin{array}{c}\text { Dialyzed } \\
\text { soluble } \\
\text { fraction }\end{array}$ \\
\hline \multirow[t]{2}{*}{$\begin{array}{l}\text { I. Premature infants } \\
\mathrm{P}-10 \\
\mathrm{P}-12 \\
\mathrm{P}-14 \\
\mathrm{P}-15 \\
\mathrm{P}-21 \\
\mathrm{P}-23 \\
\mathrm{P}-24 \\
\mathrm{P}-31 \\
\mathrm{P}-32 \\
\mathrm{P}-34 \\
\mathrm{P}-41\end{array}$} & $\begin{array}{r}0 \\
6 \\
59 \\
0 \\
81 \\
51 \\
9 \\
18 \\
0 \\
-\end{array}$ & $\begin{array}{l}0 \\
0 \\
2 \\
0 \\
4 \\
2 \\
0 \\
1 \\
0 \\
\end{array}$ & $\begin{array}{l}\mathbf{0} \\
\mathbf{2} \\
\mathbf{4} \\
\mathbf{0} \\
\mathbf{4} \\
\mathbf{1} \\
\mathbf{0} \\
\mathbf{1} \\
\mathbf{0} \\
\mathbf{0}\end{array}$ & $\begin{array}{r}0 \\
2 \\
4 \\
- \\
2 \\
-1 \\
1 \\
-\end{array}$ \\
\hline & Average 25 & 1 & 1 & 1 \\
\hline \multirow[t]{2}{*}{$\begin{array}{l}\text { II. Full-term infants } \\
\text { NB }-19 \\
\text { NB }-35\end{array}$} & $\begin{array}{l}51 \\
63\end{array}$ & $\begin{array}{l}2 \\
3\end{array}$ & $\begin{array}{l}5 \\
5\end{array}$ & $\overline{5}$ \\
\hline & Average 57 & 3 & 5 & 5 \\
\hline \multirow[t]{2}{*}{$\begin{array}{l}\text { III. Adults } \\
\mathrm{C}-23 \\
\mathrm{~A}-13 \\
\mathrm{~B}-13 \\
\mathrm{~A}-22 \\
\mathrm{~A}-25 \\
\mathrm{~A}-29\end{array}$} & $\begin{array}{l}240 \\
732 \\
192 \\
164 \\
204 \\
316\end{array}$ & $\begin{array}{r}9 \\
26 \\
8 \\
7 \\
7 \\
10\end{array}$ & $\begin{array}{l}26 \\
36 \\
21 \\
11 \\
13 \\
28\end{array}$ & $\begin{array}{l}17 \\
27 \\
- \\
25 \\
57\end{array}$ \\
\hline & Average 308 & 12 & 23 & 32 \\
\hline
\end{tabular}


TABLE III

Activity of the tyrosine oxidizing system of the soluble fraction with various standards of reference

\begin{tabular}{|c|c|c|c|c|c|c|c|c|c|c|c|c|}
\hline \multirow[b]{3}{*}{$\begin{array}{l}\text { Premature infants } \\
\text { Full-term infants } \\
\text { Adults }\end{array}$} & \multicolumn{9}{|c|}{ Oxygen uptake } & \multicolumn{3}{|c|}{$\begin{array}{l}\text { Total liver activity } \\
\mu l . O_{2} / 30^{\prime} / M^{2} \text { body } \\
\text { S.A. } \times 10^{-3}\end{array}$} \\
\hline & \multicolumn{3}{|c|}{$\begin{array}{l}\text { Number } \\
\text { of } \\
\text { subjects Range Average } \\
\mu l . / 30^{\prime} / g m . \text { wet wt. }\end{array}$} & \multicolumn{3}{|c|}{$\begin{array}{l}\text { Number } \\
\text { of } \\
\text { subjects Range Average } \\
\mu l . / 30^{\prime} / m g . N\end{array}$} & \multicolumn{3}{|c|}{$\begin{array}{l}\text { Number } \\
\text { of } \\
\text { subjects Range Average } \\
\mu l . / 30^{\prime} / m^{\prime} . D N A^{*}\end{array}$} & $\begin{array}{l}\text { Number } \\
\text { of } \\
\text { subjects }\end{array}$ & Range & Average \\
\hline & $\begin{array}{r}10 \\
2 \\
6\end{array}$ & $\begin{array}{c}0-80 \\
73-79 \\
140-612\end{array}$ & $\begin{array}{r}21 \\
76 \\
343\end{array}$ & $\begin{array}{r}11 \\
2 \\
6\end{array}$ & $\begin{array}{c}0-4 \\
5-5 \\
11-36\end{array}$ & $\begin{array}{r}1 \\
5 \\
23\end{array}$ & $\begin{array}{l}2 \\
2 \\
1\end{array}$ & $\begin{array}{l}6-15 \dagger \\
22-34\end{array}$ & $\begin{array}{c}11 \\
28 \\
135 \dagger\end{array}$ & $\begin{array}{r}10 \\
2 \\
6\end{array}$ & $\begin{array}{c}0-45 \\
44-51 \\
152-483\end{array}$ & $\begin{array}{r}15 \\
48 \\
318\end{array}$ \\
\hline
\end{tabular}

* The DNA was determined on the total homogenate; as expected, no DNA was found in the soluble fraction.

$\dagger$ The values for $\mu \mathrm{l}$. $\mathrm{O}_{2} / 30^{\prime} / \mathrm{mg}$. DNA of 6 and 15 were obtained from premature infants $\mathrm{P}-32$ and $\mathrm{P}-21$, respectively, and the value of $135 \mu \mathrm{l}$. $\mathrm{O}_{2} / 30^{\prime} / \mathrm{mg}$. DNA was obtained from the adult A-29.

the premature infants and could be considered infinitely higher when only negligible activity was present in the liver of the premature infant. These data indicate the complete absence or only slight presence of tyrosine oxidation in livers of premature infants.

Table III shows the mean values for oxidative activity, based on liver wet weight, nitrogen, desoxyribonucleic acid and total liver activity per square meter of body surface. The data show that irrespective of the standard of reference used for oxidative activity, the livers from premature infants practically always showed minimal activity and they in no instance even approximated the activity of the adult or full-term infant livers.

In Figure 1 the comparative effects of $500 \mu \mathrm{g}$. of ascorbic acid on the oxidation of tyrosine by the soluble fraction of the liver of the premature infant and the adult are shown. It is clear that this concentration maximally stimulated the adult liver

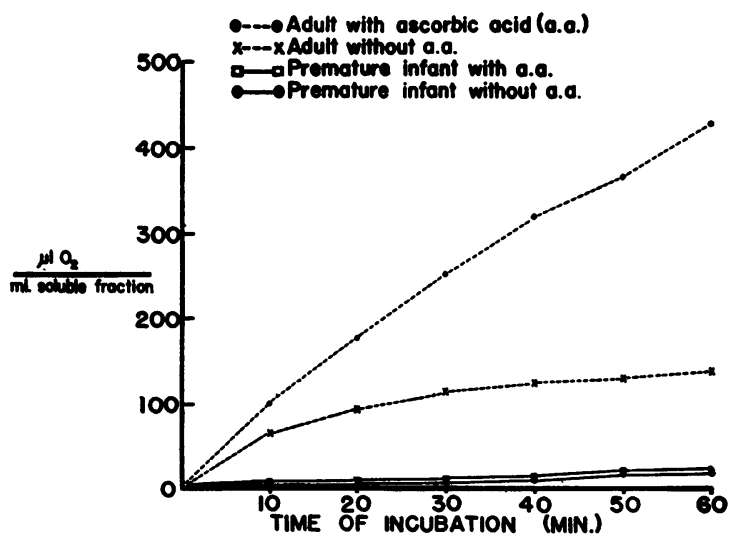

Fig. 1. The Effect of Ascorbic Acid on the Activity of the Tyrosine Oxidizing System of Human LIVER but showed no effect on the activity of the soluble fraction of the liver from the premature infant. Similar results were obtained with concentrations up to $5 \mathrm{mg}$. of ascorbic acid.

Table IV shows the effect of adding the supernatant fluid of boiled adult rat liver homogenate and the filtrate from the ultrafiltered rat liver soluble fraction to the soluble fraction of the liver of the premature infant. Neither of these additions resulted in an increase in the oxidative activity of the liver of the premature infant. The addition of the soluble fraction of the liver of the premature infant had no significant effect on the oxidative activity of the adult rat liver indicating no inhibitory activity.

Table $\mathrm{V}$ represents values for the various intermediate compounds which resulted from the oxidation of tyrosine by the soluble fraction of premature infant liver and adult liver. The adult liver selected, and used only in these observations, was obtained from an individual with carcinoma of the kidney and widespread metastases. As a consequence of the pathological changes in the liver there was a decreased oxidative activity, $28 \mu 1.0_{2} / 30^{\prime} / \mathrm{ml}$. ( $84 \mu 1.0_{2} / 30^{\prime} / \mathrm{gm}$. wet wt.) compared to the previously noted average of $102 \mu \mathrm{l}$. $\mathrm{O}_{2} / 30^{\prime} / \mathrm{ml}$. (308 $\mu \mathrm{l} . \mathrm{O}_{2} / 30^{\prime} / \mathrm{gm}$. wet wt.) for normal adult liver (Table II). This drastic reduction in oxidative activity in the pathologic adult liver nevertheless resulted in a value which remained considerably elevated above that of premature infant livers $\left(84 \mu \mathrm{l} .0_{2} / 30^{\prime} / \mathrm{gm}\right.$. wet wt. compared to the previously noted average value of $25 \mu \mathrm{l} . \mathrm{O}_{2} /$ $30^{\prime} / \mathrm{gm}$. wet wt. for premature infant liver-Table II). A pathologic adult specimen was used for the analysis to approximate the activity of premature infant liver and thus obtain minimal 
TABLE IV

The effect of additions of various fractions on tyrosine oxidation

\begin{tabular}{|c|c|c|}
\hline Subject & Material added & $\begin{array}{c}\text { Soluble } \\
\text { fraction } \\
\mu l . O_{2} / 30^{\prime} / \mathrm{ml} \text {. }\end{array}$ \\
\hline \multirow{3}{*}{$\begin{array}{c}\text { I. Premature infant } \\
\text {. } \mathrm{P}-14 \\
\mathrm{P}-14 \\
\mathrm{P}-16 \\
\mathrm{P}-16\end{array}$} & & \multirow{3}{*}{$\begin{array}{r}24 \\
15 \\
3 \\
3 \\
0\end{array}$} \\
\hline & Supernate of boiled soluble fraction of rat liver & \\
\hline & $\begin{array}{l}\text { Ultrafiltrate of soluble fraction of rat liver } \\
\text { Ultrafiltrate of soluble fraction of rat liver }\end{array}$ & \\
\hline \multirow{2}{*}{$\begin{array}{l}\text { II. Adurltat } \\
\text { AR-16 } \\
\text { AR-16 }\end{array}$} & & \multirow{2}{*}{$\begin{array}{l}324 \\
294\end{array}$} \\
\hline & Soluble fraction of premature infant liver & \\
\hline
\end{tabular}

biochemical differences. The biochemical values obtained with the premature infant liver were more significant since distinctly higher values were obtained with the liver of an adult having had a disease which led to severe parenchymatous disruption. This approach again obviates the criticism that premature infant liver was more disrupted by autolysis after death than normal adult liver. In this analysis (Table V) all of the known intermediates were determined with a combination of various methods. The concentration of p-hydroxyphenylpyruvic acid was determined following incubation of the soluble fraction in an atmosphere of nitrogen $(.04 \mathrm{mg}$. per $\mathrm{ml}$. for premature infant liver and $.17 \mathrm{mg}$. per $\mathrm{ml}$. for adult liver) and the presence of this substance was confirmed in both instances by the subsequent formation and isolation of the 2-4 dinitrophenylhydrazones. When other samples of the same tissue were incubated in air there was a trace of 2-4 dinitrophenylhydrazone formed after the incubation of the premature infant liver and none after adult liver. These results, together with the identity of the results obtained with the Briggs' reaction $(.08 \mathrm{mg}$. per $\mathrm{ml}$.) and with iodometry (.07 mg. per ml.), established that in the case of the adult liver the Briggs' reacting material was all homogentisic acid. On the other hand, only

TABLE V

Protocol of a complete experiment using the soluble fraction of human liver

\begin{tabular}{|c|c|c|c|c|c|}
\hline \multirow[b]{2}{*}{ Determination } & \multirow[b]{2}{*}{$\begin{array}{l}\text { Substance } \\
\text { determined }\end{array}$} & \multicolumn{2}{|c|}{$\begin{array}{c}\text { Premature infant } \\
\text { liver }\end{array}$} & \multicolumn{2}{|c|}{ Adult liver } \\
\hline & & In air & $\begin{array}{c}\text { Under } \\
\text { nitrogen }\end{array}$ & In air & $\begin{array}{c}\text { Under } \\
\text { nitrogen }\end{array}$ \\
\hline $\begin{array}{l}\text { Oxygen uptake } \\
\mu \mathrm{l} . / 30^{\prime} / \mathrm{ml} \text {. }\end{array}$ & & 1 & 0 & 28 & 0 \\
\hline $\begin{array}{l}\text { Millon test* } \\
\text { mg./ml. }\end{array}$ & $\begin{array}{l}\text { Tyrosine }+ \\
\text { p-Hydroxyphenyl- } \\
\text { pyruvic acid }\end{array}$ & 1.52 & 1.55 & 1.47 & 1.64 \\
\hline $\begin{array}{l}\text { Briggs' test* } \\
\text { mg./ml. }\end{array}$ & $\begin{array}{l}\text { p-Hydroxyphenyl- } \\
\text { pyruvic }+ \\
\text { Homogentisic acid }\end{array}$ & .08 & .04 & .08 & .17 \\
\hline $\begin{array}{l}\text { Iodometry* } \\
\mathrm{mg} \cdot / \mathrm{ml} \text {. }\end{array}$ & Homogentisic acid & .02 & 0 & .07 & 0 \\
\hline $\begin{array}{l}\text { Spectrophotometry* } \\
\quad(\lambda 320)\end{array}$ & $\begin{array}{l}\text { Maleylacetoacetic } \\
\text { acid }\end{array}$ & + & - & ++ & - \\
\hline $\begin{array}{c}\text { Dinitrophenyl- } \\
\text { hydrazones }\end{array}$ & $\begin{array}{l}\text { p-Hydroxyphenyl- } \\
\text { pyruvic acid }\end{array}$ & \pm & + & - & + \\
\hline $\begin{array}{l}\text { Nitrogen } \\
\text { mg./ml. }\end{array}$ & & & & & \\
\hline
\end{tabular}

* All determinations done after 60 minutes of incubation. 
a part of the Briggs' reacting material in the case of the premature infant liver could be accounted for by iodometry (.02 $\mathrm{mg}$. per $\mathrm{ml}$. leaving approximately $.06 \mathrm{mg}$. per $\mathrm{ml}$. by difference). When the premature infant liver and adult liver were incubated in air, the end-product maleylacetoacetic acid was detected in both cases. A greater amount of this substance was present when the adult liver was used. The lack of homogentisic acid (iodometry) and maleylacetoacetic acid (spectrophotometric analysis) when the samples were incubated in nitrogen proved the presence of an anaerobic environment. Thus, by the composite use of various methods the various individual steps in the oxidation of tyrosine were ascertained, and the differences between the premature infant liver and the adult liver were emphasized.

\section{DISCUSSION}

These studies show that the liver of the premature infant has little or no tyrosine oxidizing activity. The activity of the tyrosine oxidizing system is greater in the liver of the newborn infant and notably greater in the liver of the adult. These differences appear to be real and apparently do not depend on the conditions of obtaining specimens as indicated by the rat autopsy model and verified by the finding of a very low oxidative activity in the liver of the fetal rat (17).

The premature infants in this study were younger and smaller than the subjects in the previous clinical studies (8) and the in vitro activity of fractions of their livers was not stimulated by the addition of ascorbic acid or dichlorophenolindophenol. The addition of ultrafiltrates and boiled supernates of adult rat liver did not activate the liver of the premature infant nor did the soluble fraction of the liver of the premature infant inhibit the activity of the liver of the adult rat. These experiments established the absence of nonprotein inhibitors and the presence of the non-protein activators in the liver of the premature infant. A highly significant feature of this study is the demonstration that the activity of the tyrosine oxidizing system increased at a greater rate from prematurity to adulthood than the concomitant increases in cell nitrogen or for that matter any other cellular standard of reference. The over-all relationship of enzyme development to systemic development and differentiation has been well summarized by Boell (26) and Needham (27) who have pointed out that the development of such molecules as enzymes patterns morphologic development. Boell (26) states that enzymes with general and vital functions apparently develop first and keep pace with cell growth whereas enzymes with more specific and less vital functions develop more slowly and later accelerate at a faster rate.

The data previously presented indicate that the low activity of the tyrosine oxidizing system in the liver of the premature infant is not due to a lack of coenzymes or non-protein activators but to the actual absence of apoenzyme. Table $\mathrm{V}$ shows that blockage with nitrogen gas at the first step of tyrosine oxidation, using equivalent quantities of tissue nitrogen and an excess of $\alpha$-ketoglutarate and pyridoxal phosphate, resulted in the production of considerably less p-hydroxyphenylpyruvic acid by premature (.04 mg. per ml. tissue) than adult livers (.17 mg. per ml. tissue). This transamination was studied more completely in rats (17) and it was similarly observed that the tyrosine transaminase apoenzyme was in much lower concentration in the liver of fetal rats than in the liver of adult rats. Transaminase activity may possibly reflect the activity of each of the individual constituent enzymes of the entire enzyme system.

No definitive evidence is at present available to explain the apparent discrepancy between these results and the previous clinical observations (8, 9). One may assume that early in the life of the premature infant only a small amount of tyrosine is converted to p-hydroxyphenylpyruvate due to the paucity of the tyrosine transaminase apoenzyme. This small quantity of p-hydroxyphenylpyruvate would require only a meager concentration of $\mathrm{p}$-hydroxyphenylpyruvate oxidase for oxidation and the apoenzyme could be activated completely by minimal stores of intrinsic ascorbic acid. The above discrepancy could then be readily explained by the further assumption that as the premature infant develops more apoenzymes are synthesized and extrinsic ascorbic acid is necessary to activate the increased $\mathrm{p}$-hydroxyphenylpyruvate oxidase apoenzyme. When this cofactor is not given to premature infants on a high protein diet, the tyrosine oxidizing system is blocked $(8,9)$ at the stage of conversion of p-hydroxyphenylpyru- 
vate to homogentisate; and tyrosine and p-hydroxyphenylpyruvic acid appear in the urine. Observations on premature infants are in progress to determine the in vivo and in vitro veracity of this theory.

The inconsistently beneficial effect of folic acid on the hydroxyphenyluria of premature infants (14), monkeys (13), and guinea pigs (12) may depend on augmented nonspecific protein synthesis or even on synthesis of the specific apoenzymes. In either case there would result a greater utilization by anabolism or catabolism, respectively, of the substrate presented, i.e., tyrosine. The mechanism or mechanisms involved in the reduction of tyrosyluria by the administration of ACTH is being studied in animals.

\section{SUM MARY}

1. The activity of the tyrosine oxidizing system of the liver of the human adult is 10 to 30 times greater, and the activity of the liver of the fullterm infant 3 to 5 times greater, than the hepatic activity of the premature infant. These marked differences were consistent, irrespective of the standard of reference used.

2. The in vitro addition of large amounts of ascorbic acid did not stimulate the oxidative activity in premature infant liver in contrast to its stimulating effect on adult liver.

3. Premature infant liver does not lack thermolabile or thermostable non-protein activators nor does it contain non-protein inhibitors of the tyrosine oxidizing system.

4. A protocol is presented in which each intermediate of the tyrosine oxidizing system was studied. The evidence suggests that the premature infant in the first few days after birth lacks apoenzyme and that the apoenzyme subsequently develops at a rate in excess of systemic cell or tissue growth.

\section{REFERENCES}

1. Knox, W. E., and LeMay-Knox, M., The oxidation in liver of L-tyrosine to acetoacetate through p-hydroxyphenylpyruvate and homogentisic acid. Biochem. J., 1951, 49, 686.

2. Crandall, D. I., and Halikis, D. N., Homogentisic acid oxidase. I. Distribution in animal tissues and relation to tyrosine metabolism in rat kidney. $\mathrm{J}$. Biol. Chem., 1954, 208, 629.
3. Knox, W. E., The metabolism of phenylalanine and tyrosine in A Symposium on Amino Acid Metabolism, McElroy, W. D., and Glass, H. B., Eds., Baltimore, Johns Hopkins Press, 1955, p. 836.

4. Lan, T. H., and Sealock, R. R., The metabolism in vitro of tyrosine by liver and kidney tissues of normal and vitamin C-deficient guinea pigs. J. Biol. Chem., 1944, 155, 483.

5. Sealock, R. R., Goodland, R. L., Sumerwell, W. N., and Brierly, J. M., The rôle of ascorbic acid in the oxidation of L-tyrosine by guinea pig liver extracts. J. Biol. Chem., 1952, 196, 761.

6. $\mathrm{LaDu}$, B. N., Jr., and Greenberg, D. M., Ascorbic acid and the oxidation of tyrosine. Science, 1953, $117,111$.

7. Williams, J. N., Jr., and Sreenivasan, A., Further studies on the cofactors of the liver tyrosine oxidase system. J. Biol. Chem., 1953, 203, 605.

8. Levine, S. Z., Marples, E., and Gordon, H. H., A defect in the metabolism of tyrosine and phenylalanine in premature infants. I. Identification and assay of intermediary products. J. Clin. Invest., 1941, 20, 199.

9. Levine, S. Z., Tyrosine and phenylalanine metabolism in infants and the role of vitamin C. Harvey Lect., 1946-1947, 42, 303.

10. Rogers, W. F., Jr., and Gardner, F., Tyrosine metabolism in human scurvy. J. Clin. Invest., 1949, 28, 806.

11. Gabuzda, G. J., Jr., Effect of citrovorum factor upon tyrosine metabolism in clinical scurvy. Proc. Soc. Exper. Biol. \& Med., 1952, 81, 62.

12. Woodruff, C. W., Cherrington M. E., Stockell, A. K., and Darby, W. J., The effect of pteroylglutamic acid and related compounds upon tyrosine metabolism in the scorbutic guinea pig. J. Biol. Chem., 1949, 178, 861.

13. Salmon, R. J., and May, C. D., The effect of folinic acid (citrovorum factor) and of cortisone on the metabolism of tyrosine in the scorbutic monkey. Arch. Biochem. \& Biophys., 1951, 32, 220.

14. Nitowsky, H. M., Govan, C. D., Jr., and Gordon, H. H., Effect of hemopoietic and other agents on the hydroxyphenyluria of premature infants. Am. J. Dis. Child., 1953, 85, 462.

15. Levine, S. Z., Barnett, H. L., Bierman, C. W., and McNamara, H., Effect of ACTH and some adrenocortical steroids on the metabolism of tyrosine and phenylalanine in premature infants. Science, 1951, 113, 311.

16. Basinski, D. H., Williams, J. D., and Freund, H. A., The effect of cortisone and adrenocorticotropic hormone on tyrosine metabolism in the scorbutic guinea pig. J. Biol. Chem., 1952, 197, 433.

17. Kretchmer, N., McNamara, H., Levine, S. Z., and Barnett, H. L., Unpublished observations.

18. LaDu, B. N., Jr., and Greenberg, D. M., The tyrosine oxidation system of liver. I. Extracts of rat liver acetone powder. J. Biol. Chem., 1951, 190, 245. 
19. Williams, J. N., Jr., and Sreenivasan, A., A study of the cofactors required by the tyrosine oxidase system of liver. J. Biol. Chem., 1953, 203, 109.

20. Ma, T. S., and Zuazaga, G., Micro-Kjeldahl determination of nitrogen. $\mathrm{A}$ new indicator and an improved rapid method. Indust. \& Engin. Chem., Anal. Ed., 1952, 14, 280.

21. Schneider, W. C., Intracellular distribution of enzymes. I. The distribution of succinic dehydrogenase, cytochrome oxidase, adenosinetriphosphatase, and phosphorus compounds in normal rat tissues. J. Biol. Chem., 1946, 165, 585.

22. Dische, $Z$., Uber einige neue charakteristische Farbreaktionen der Thymonukleinsäure und eine Mikromethode zur Bestimmung derselben in tierischen Organen mit Hilfe dieser Reaktionen. Mikrochemie, 1930, 8, 4.
23. Medes, G., A new error of tyrosine metabolism: Tyrosinosis. The intermediary metabolism of tyrosine and phenylalanine. Biochem. J., 1932, 26, 917.

24. Neuberger, A., and Webster, T. A., Studies on alcaptonuria. 3. Experimental alcaptonuria in rats. Biochem. J., 1947, 41, 449.

25. Cavallini, D., and Frontali, M., Quantitative determination of keto-acids by paper partition chromatography. Biochim. et Biophys. Acta, 1954, 13, 439.

26. Boell, E. J., Energy exchange and enzyme development during embryogenesis in Analysis of Development, Willier, B. H., Weiss, P. A., and Hamburger, V., Eds., Philadelphia, W. B. Saunders Co., 1955 , p. 520.

27. Needham, J., Chemical Embryology. Cambridge, England, Cambridge Univ. Press, 1931. 